\title{
Implementation of PDCA Cycle to Improve Quality of Animal Protein Levels in Traditional Medicinal Products
}

\author{
Hayu Kartika ${ }^{1}$, Meike Elsye Beatrix ${ }^{2}$, Atep Afia Hidayat ${ }^{3}$, Candra Setia Bakti ${ }^{4}$ \\ Faculty of Engineering, Industrial Engineering Program, Universitas Mercu Buana, Jakarta, 11650 ${ }^{1-3}$ \\ PT Milenia Sistem Konsultan, Tangerang, $15331^{4}$ \\ Indonesia
}

\begin{abstract}
This research is carried out in Traditional medicine a company, at Jakarta. Which is one of the pharmaceutical companies in Indonesia. This company has conducted research from the year 2000 to find "active ingredients of medicines" from natural ingredients native to Indonesia. This herbal medicine production process produces animal protein extract product derived from cork fish that are rich in albumin. However, when the evaporation process the protein content produced is below the set standards, so that the impact on protein extraction result is less than the maximum. The evaporation process aims to get extracts that are highly concentrated by efforts to reduce the solvent in the product so that it only leaves the active ingredients alone. By evaporating the product in a vessel accompanied by a vacuum so that the activity level of protein content contained in the product can be increased. To prevent the decrease in activity of protein levels, resulting from evaporation. Effort were made to increase the activity of protein levels in the evaporation process using the Plan-Do-Check-Action method, the results obtained from the improvement process with the PDCA pattern this was found to be improved by increasing protein levels by $73.43 \%$, with these results expected to optimize the efficacy and quality of the medicinal product for consumption
\end{abstract}

Keywords: PDCA, Evaporation Process, Quality, Animal Protein Content, Traditional Medicine.

\section{INTRODUCTION}

In this modern era there are still many people who use traditional medicine as a substitute for chemical drugs. The majority of people prefer herbal treatment because natural ingredients are considered safer. Herbal medicine itself can be get from plants and animals, where for medicinal plants is very popular used as a traditional raw material, if the plant is able to be produced as a standardized herbal medicine (OHT) then will have a higher selling value and stronger ability both domestic and international market. In addition, herbal medicines are made from animals, one of them can be obtained from the cork where it is very rich in albumin, one type of protein is important for the human body as a process of wound healing, cancer, stroke, renal failure and diabetes mellitus, as well as having an L-arginine acid compound that will improve wound healing [1-4]. Cork fish based on other studies report having a very high protein content compared to other types of fresh fish.. This research conducted a sample examination of the evaporation process obtained an average protein content of $148.45 \mathrm{mg} / \mathrm{ml}$ and did not meet the standard stipulated, where the requirement of the evaporation resulting protein is $\geq 150 \mathrm{mg} / \mathrm{ml}$. because the protein levels are below standard so it is necessary to act to prevent the effectiveness of protein levels. To prevent the decrease in protein activity resulting from evaporation, efforts were made to increase protein activity in the evaporation process with the Plan-Do-Check- Actionmethod wherethis PDCA pattern has not been implemented by the traditional medicine manufacturer as the basis of the concept of continuous improvement in order to achieve the appropriate and desired product results. This is also because using PDCA caneffectively improve quality as an ongoingaction [6-8]. 


\section{RESERCH METHODOLOGY}

\subsection{Data Collection Techniques}

The following is the data information needed in the collection of data in this study, namely:

1.Identify unfulfilling production data by using a check sheet

2.Observation and interview of protein processing process

\subsection{Repair Steps}

Here is an overview of the research steps that will be done in this research, namely:

\section{a.Planning}

The planning stage, is a key stage of the success of the research because in this stage discusses from the beginning the determination of the problem improvement of the evaporation process, See from several influence factors namely $4 \mathrm{M}$ (human, machine, method and material)

b.Implementation of Improvement (do)

The implementation of the fix is adjusted to the factors that cause the problem that is known before. After determining the next problem factor determines the corrective action that will be done by using $5 \mathrm{~W}+1 \mathrm{H}$ analysis and in the implementation c.Repair Evaluation (check)

This evaluation stage is carried out by monitoring the results of the improvement. Whether the effects of improvement can increase protein activity

d.Standardization (Action)

At this stage, prevention implementation is carried out to avoid recurring problems by standardizing the work.

\section{DATA COLLECTION AND PROCESSING}

\subsection{Collection}

The data obtained comes from sampling results in extraction, separation and evaporation processes. Then analyze the activity of protein levels in the laboratory using Lowry method. Below are the steps of the production sample testing process:

A.Material Cutting Preparation

It is a process of cutting raw materials that have been stored in the freezer at temperatures $\left(-2^{\circ} \mathrm{C}\right.$ to $\left.-20^{\circ} \mathrm{C}\right)$ from a square shape with a size of $\pm 60 \times 60 \mathrm{~cm}$ into small pieces with a size of $12 \times 12 \mathrm{~cm}$.

B.Extraction

It is the second process after preparation, this process includes boiling raw materials with the addition of mixed materials as well as solvents in the form of purified water.

C.Separation

It is the third process after extraction, in this process the result of the extraction process is carried out separation between the amp and the material.

D.Micro Filtration

It is the fourth process after the process of separation, the result of material from the process of separation is micro-filtering.

E.Evaporation

It is the fifth process after micro filtration, this process is the process of tightening the concentration of the product, the result of micro-filtering with more volumes concentrated by means of vacuum evaporation so that the volume is reduced and the concentration increases.[9]

\section{Protein Content Checking Method}

Phenolic group detection reagents such as folin and ciocalteu reagents have been used in the determination of protein concentrations by Lowry (1951) which came to be known as the Lowry method.In the simplest form of folin reagents ciocalteu a pat detect tyrosine residue (in proteins) because the phenolic content in the residue is able to reduce Phosphotungstat and Phosphomilib date, which is the main constituent of the folin-Ciocalteu reagent, being a blue tungsten and molybdenum [10] .

The results of this reduction show a wide peak of absorbin the red area. The sensitivity of this method of folinciocalteu is significantly improved when combined with $\mathrm{Cu}$ ions [10] .

a.Making a Witness

1)Solution $A$

Put $4.0 \mathrm{~g}$ of $\mathrm{NaOH}$ in a $1 \mathrm{~L}$ be chemical glass, then fill it with $500 \mathrm{ml}$ of PW water. Add $20.0 \mathrm{~g} \mathrm{Na} \mathrm{CO}_{3}$ (analytical grade)then stirer until perfectly dissolved. Add PW water to the total volume of the solution $1 \mathrm{~L}$. Store the solution in the coldroom $\left(2-8^{\circ} \mathrm{C}\right)$.

2)Solution $B$

Put 0.25 g cuso $_{4}$ (analytical grade) into a $50 \mathrm{ml}$ measuring cup, then dissolve with PW water up to a total volume of 25 ml.Store in cold room $\left(2-8^{\circ} \mathrm{C}\right)$.

3)Solution $C$ 
Put $0.5 \mathrm{~g}$ of K-Na-Tartrate (analytical grade) into a $50 \mathrm{ml}$, then dissolve with PW water up to a volume of $25 \mathrm{ml}$. Store in cold room $\left(2-8^{\circ} \mathrm{C}\right)$.

b. Reagent Lowry

Combine solutions A B and C with a ratio of 98:1:1. The solution is made fresh.

c. Standard Curve Making

1) BSA solution $2 \mathrm{mg} / \mathrm{ml}$ (freshly made)

Weight $20.0 \mathrm{mg}$ Bovine serum albumin (BSA) (analytical grade)then put in a measuring pumpkin $10 \mathrm{ml}$. Add PW water to the limit mark, then shake until perfectly dissolved.

2) Make BSA solution in 6 concentrations, namely:

Table 1. BSA Standards

\begin{tabular}{|c|c|c|c|c|c|c|c|}
\hline Reagent $(\mu \mathrm{L})$ & Blank & $\begin{array}{c}\text { Std 1 } \\
(250 \mu \mathrm{g} / \mathrm{ml})\end{array}$ & $\begin{array}{c}\text { Std 2 } \\
(500 \mu \mathrm{g} / \mathrm{ml})\end{array}$ & $\begin{array}{c}\text { Std 3 } \\
(750 \mu \mathrm{g} / \mathrm{ml})\end{array}$ & $\begin{array}{c}\text { Std 4 } \\
(1000 \mu \mathrm{g} / \mathrm{ml})\end{array}$ & $\begin{array}{c}\text { Std 5 } \\
(1250 \mu \mathrm{g} / \mathrm{ml})\end{array}$ & $\begin{array}{c}\text { Std 6 } \\
(1500 \mu \mathrm{g} / \mathrm{ml})\end{array}$ \\
\hline $\begin{array}{c}\text { BSA stock } \\
(2000 \mu \mathrm{g} / \mathrm{mL})\end{array}$ & 0 & 125 & 250 & 375 & 500 & 625 & 750 \\
\hline $\begin{array}{c}\text { Water } \\
\text { PW }(\mu \mathrm{L})\end{array}$ & 1000 & 875 & 750 & 625 & 500 & 375 & 250 \\
\hline
\end{tabular}

3) Mix standard stock BSA solution and PW water in microtube $1.5 \mathrm{ml}$ according to the composition on the table. Vortkes for 5 seconds. Make a solution of duplo.

4) Pipettes of $200 \mu \mathrm{l}$ each standard solution (1-6) and blanko into the test tube.

5) Patch $2.0 \mathrm{ml}$ reagent Lowry then vorteks 5 seconds.

6) Let the reaction mixture stand for 10 minutes at room temperature.

7) Add $200 \mu \mathrm{l}$ reagent phenol FolinCiocalteu, then vortext 5 seconds.

8) Let stand the reaction mixture for 30 minutes at room temperature, then vorteks 5 seconds.

9) Measure absorbance at wavelengths of $750 \mathrm{~nm}$.

10) Create a standard curve with the $X$ axis as concentration $(\mu \mathrm{g} / \mathrm{ml})$ and $y$-axis as absorbance.

11) Create a linear regression equation with a minimum $R^{2}$ of 0.990 from 6 points.

d. Inspection Procedure

1) Pipette $5.0 \mathrm{ml}$ sample then put in pumpkin measuring $10 \mathrm{ml}$. Add pw water to the limit mark then whisk until dissolved. Centrifugation of the solution, at $5000 \mathrm{rpm}$ for 5 minutes. Take supernatan as a sample solution. Make a solution of duplo.

2) Pipette $200 \mu \mathrm{l}$ sample solution into the test tube.

3) Add $2.0 \mathrm{ml}$ reagent Lowry then vorteks 5 seconds.

4) Incubation for 10 minutes, add $200 \mu$ Folinceaceltau.

5) Incubation of reaction mixture for 30 minutes at room temperature.

6) Measure absorbance at wavelengths of $750 \mathrm{~nm}$.

The data used in this study is the total data on the production of extraction, separasi and evaporation processes for 2 months starting in January 2020 to February 2020 and the following authors present in the form of data tables not meeting standards. In the table below is the average results of the analysis of the activity of protein content products, there are 2 types of product outputs coded BAF01 \& BAF02.

Table 2. Average number of analyal activity results in protein content products BAF01\&BAF02 period January - February 2020

\begin{tabular}{|c|c|c|c|c|c|}
\hline No. & Products & Process & $\begin{array}{c}\text { Standard } \\
(\mathrm{mg} / \mathrm{ml})\end{array}$ & $\begin{array}{c}\text { Protein Levels } \\
(\mathrm{mg} / \mathrm{ml})\end{array}$ & Description \\
\hline 1 & BAF01 & Extraction & 20 & 26.83 & Meeting Standards \\
\hline 2 & BAF02 & Extraction & 20 & 23.63 & Meeting Standards \\
\hline 3 & BAF01 & Separation & 20 & 25.94 & Meeting Standards \\
\hline 4 & BAF02 & Separation & 20 & 23.63 & Meeting Standards \\
\hline 5 & BAF01 & Evaporation & 150 & 178.68 & Meeting Standards \\
\hline 6 & BAF02 & Evaporation & 150 & 148.50 & Not Meeting Standards \\
\hline
\end{tabular}

(Source : Company Internal Data , 2020)

Based on table 2, it can be noted that in BAF02 products the results of the evaporation process are obtained activities of protein levels that do not meet the standard (NMS). The product is said to be NMS because the average value of protein activity obtained at $148.50 \mathrm{mg} / \mathrm{ml}$ is still below the standard stipulated which is $150 \mathrm{mg} / \mathrm{ml}$.

As for the results of weekly data analysis of protein activity, activity from the results of the evaporation process during the period January - February 2020 will be presented in the table below. 
International Journal of Advances in Scientific Research and Engineering (ijasre), Vol 6 (10), October -2020

Table 3. Weekly data on analytic activity results in BAF02 protein levels

period January - February 2020

\begin{tabular}{|c|c|c|c|c|c|c|}
\hline No. & Date & Process & $\begin{array}{c}\text { Protein } \\
\text { Levels } \\
(\mathrm{mg} / \mathrm{ml})\end{array}$ & $\begin{array}{c}\text { Spec } \\
(\mathrm{mg} / \mathrm{ml})\end{array}$ & Description & Week \\
\hline 1 & $06-01-2020$ & Evaporation & 148.40 & 150 & NMS & Week 1 \\
\hline 2 & $20-01-2020$ & Evaporation & 149.12 & 150 & NMS & Week 3 \\
\hline 3 & $22-01-2020$ & Evaporation & 148.23 & 150 & NMS & Week 4 \\
\hline 4 & $05-02-2020$ & Evaporation & 148.45 & 150 & NMS & Week 2 \\
\hline 5 & $12-02-2020$ & Evaporation & 148.45 & 150 & NMS & NMS \\
\hline 6 & $19-02-2020$ & Evaporation & 148.46 & 150 & & Week 4 \\
\hline 7 & $26-02-2020$ & Evaporation & 148.44 & 150 & & \\
\hline
\end{tabular}

(Source : Company Internal Data, 2020)

Based on table 2 above known the average value of protein activity resulting from evaporation process obtained during the period June - July 2018 is $148.50 \mathrm{mg} / \mathrm{ml}$. The value is still below the set standard of $150 \mathrm{mg} / \mathrm{ml}$. Therefore, in the process of evaporation of product BAF02 became the focus of research because it obtained the activity of protein levels that NMS and this is not desired by the company.

\subsection{Processing \\ Planning (Plan)}

The planning in this improvement process discusses determining the condition of the problem that will be studied about the cause of protein levels that do not conform to the standards, and analyzes the root of the problem. Based on table 3 and table 4 the evaporation process is a process that needs to be improved so it is necessary to look at the analysis of current conditions.

Table 4. Causative And Influence Factors

\begin{tabular}{|l|l|l|}
\hline \multicolumn{1}{|c|}{ Factors } & \multicolumn{1}{|c|}{ EXISTING CONDITIONS } & \multicolumn{1}{c|}{ Influence } \\
\hline Man & The operator left the evaporation room. & There is a strong explosion (bumping). \\
\hline MACHINE & Water change schedule for heater once a month. & The engine temperature becomes less stable. \\
\hline METHODE & Use old work instructions & The viscosity of the liquid is too concentrated. \\
\hline MATERIAL & Suppliers of materialsare different. & The initial protein content is different. \\
\hline
\end{tabular}

(Source : Observations of researchers, 2020)

Based on table 3 several causes and influences of the current condition, there are several problems that affect the decrease in the quality of protein levels resulting in products that do not match spec. To Find out the root of the problem of these factors then perfom analysis by using fishbone diagram as a tool to find out the root cause of the problem that accurred. The following is a description of fishbone diagram of the problem of lowering the quality of protein levels in the evaporation process that causes the results not to enter into spec:

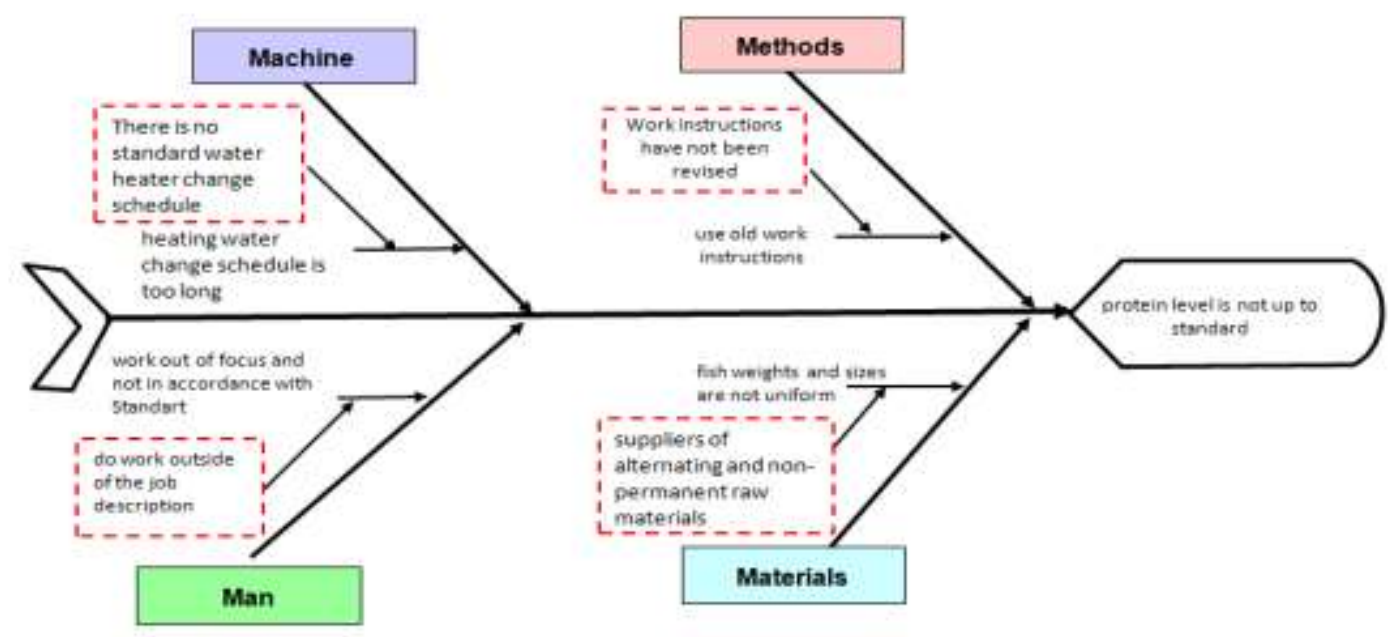

Figure 1.FishboneDiagram

(Source: Observations of researchers, 2020) 
Fishbone diagram in figure 1 above there are four (4) significant causative factors and need to be considered, namely:

1) Human Factor (Man)

The thing to note for this factor is that the operator is less focused, because the operator is doing other work. human resource management is necessary because it is a matter of concern and the most important part of the company[11]

2) Machine Factor

The thing to note for this factor is that the schedule of the change of air heater is too long that is within 1 month so it can cause less stable temperature.

3) Material Factor

The thing to note for this factor is the weight of different fish sizes.

4) Method Factor (Method)

The thing to note for this factor is the inappropriate working instructions at the time of filling the material into the evaporation machine. There needs to be an improvement and evaluation of the new work instructions.

\section{Implementation improvement (Do)}

After determining the root of the existing problem, then take steps to repair that will be performed. Improvements were made gradually from March - June 2020.

\section{A. Drafting Step Improvement}

After analysis of causal cause by using the fishbone diagram, the strategy to develop a step improvement to overcome the results of the analysis of the activity of protein levels in the evaporation process that does not meet the standard so that the results are entered into the spec so that there is increased quality of protein levels in the process

In research in evaporation process can be prepared step-step improvement to be done. The preparation of step-step improvement can be done using the method $5 \mathrm{~W}+1 \mathrm{H}$ (What, Why, Who, Where, When and How) as follows:

Table 4.Analysis $5 \mathrm{~W}+\mathbf{1 H}$

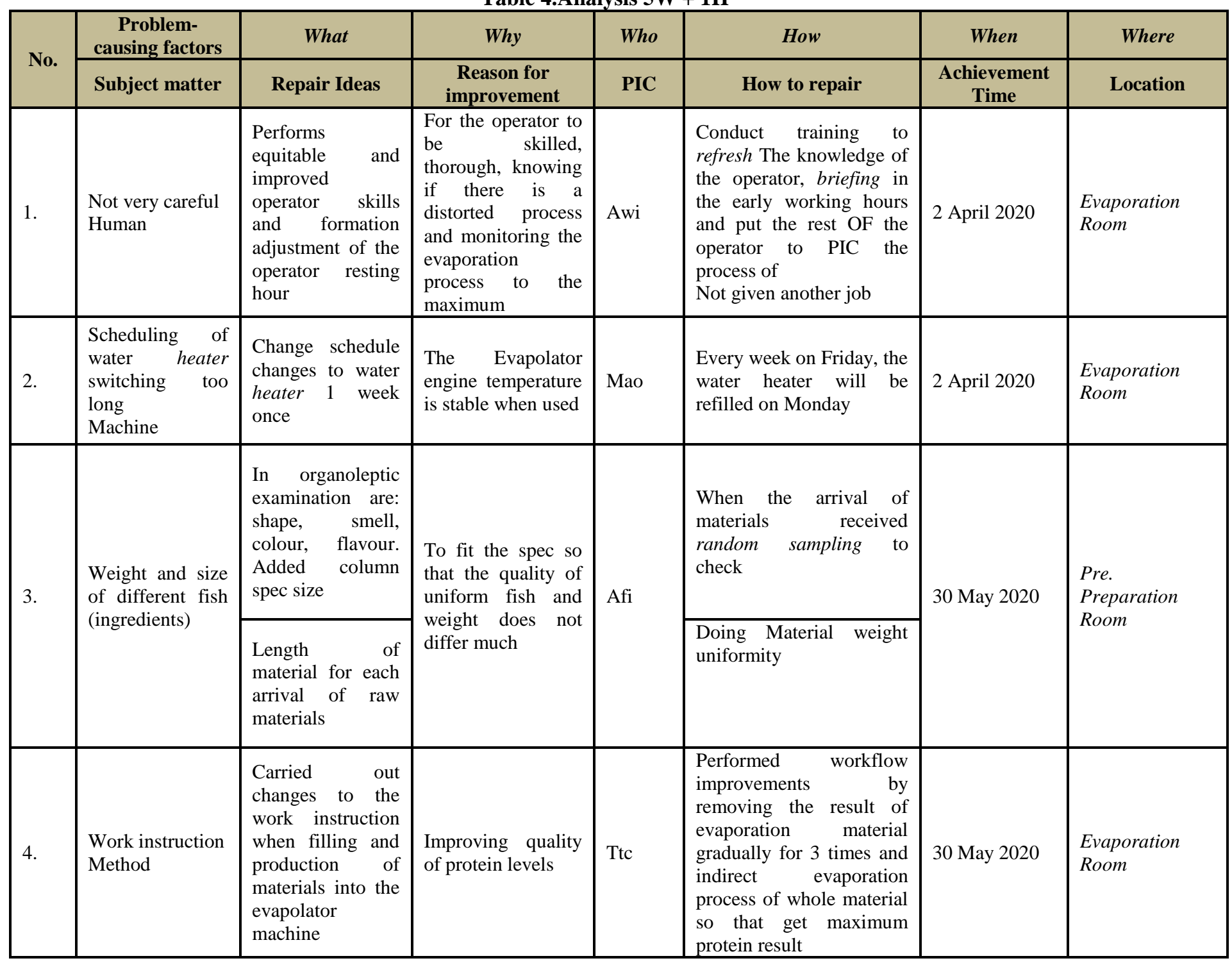




\section{Evaluation of implementation of repair and activities (Check)}

After the improvement in the do stage, then at this stage will be the result of the implementation that has been done whether all the repair process as expected by testing the protein levels, the research results will be summarized in the table 6.8 . Below

Table 5. Data Protein content test result BAF02 product after repair

\begin{tabular}{|l|l|l|l|l|l|}
\hline No. & Date & Process & $\begin{array}{l}\text { Protein } \\
\text { content } \\
(\mathbf{m g} / \mathbf{m l})\end{array}$ & $\begin{array}{l}\text { Standard } \\
(\mathbf{M g} / \mathbf{m l})\end{array}$ & Description \\
\hline 1. & $02-06-2020$ & Evaporated & 155.44 & 150 & Meet the standards \\
\hline 2. & $09-06-2020$ & Evaporated & 182.04 & 150 & Meet the standards \\
\hline 3. & $16-06-2020$ & Evaporated & 207.09 & 150 & Meet the standards \\
\hline 4. & $23-06-2020$ & Evaporated & 207.70 & 150 & Meet the standards \\
\hline 5. & $30-06-2020$ & Evaporated & 221.39 & 150 & Meet the standards \\
\hline 6. & $06-07-2020$ & Evaporated & 245.72 & 150 & Meet the standards \\
\hline \multicolumn{2}{|l|}{ Average } & $\mathbf{2 0 3 . 2 3}$ & & \\
\hline
\end{tabular}

(Source: Observations of researchers, 2020)

From the table above visible protein levels resulting in considerable increase, even protein results exceed the predefined limits, these improvements have quite significant results in the quality of the product

\section{Standardization (Action)}

In the process of repair required standardization to prevent the occurrence of the same problem. In addition, standardization is also useful to improve the capability of operators in monitoring process, equipment, materials, and surrounding environment. The standardization is as follows:

1).change clock setting

With the setting of the break hour, it can avoid the miss between operators.

2)change scheduling engine water heater evapolator

For the problem of switching water heater The Evapolator machine in the production area is the responsibility of the production parts. But for the reduction is done by the operator in the production area. Check Sheet is a tool to control the adjusted change of water heater.

3)addition of fields to organoleptic acceptance of the arrival of fish raw materials

Propose addition of column for checking size to be uniform fish weight.

4)Change of work instruction

By doing the revision of the work instruction Evapolator process can improve the quality of activity of protein levels.

\section{RESULT}

Improvements made using the concept of PDCA method, have provided good results namely: the onstility of good effectiveness. The value of increasing protein levels has been summarized in figure 2, seen from the comparison of results before the repair process and after the repair of the process

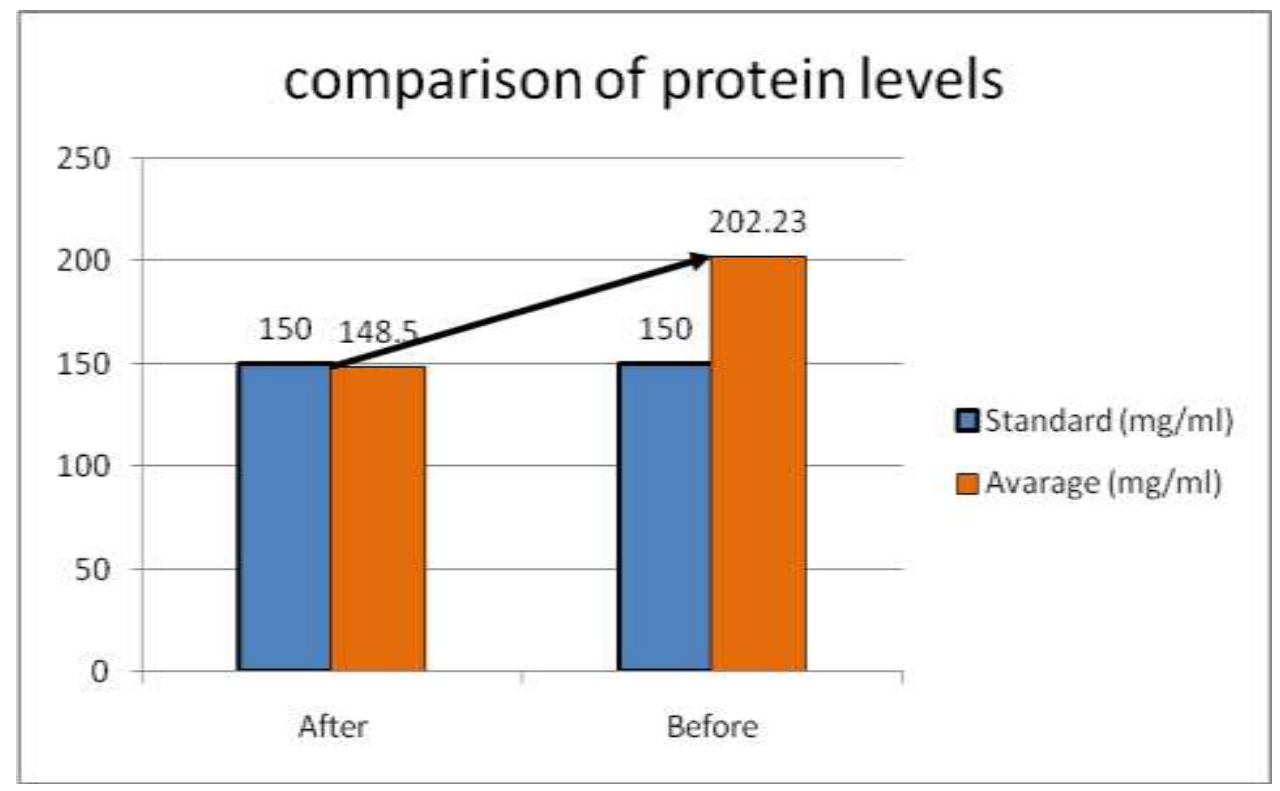

Figure 2. Average sample comparison

(Source: Observations of researchers, 2020) 
From the picture above there is an increase in the average protein level between before and after the repair of about $73.43 \%$, from the average before the improvement in the process, this can be said to improve the process done quite successfully in the effort of improving the quality of protein in the drug, so that the benefits that can be from consuming this drug is expected to be more optimal.

\section{CONCLUSION}

From the results and research discussion above, there are several conclusions that can be taken, namely:

1. Factors that result in decreased levels of protein in the evaporation process is caused by 4 main factors namely human, machine/tools, materials, and methods where the root causes of occurrence are:

A. The occurrence of strong explosion (bumping) so that the Product is sucked by the vacuum pump evaporator because the lack of accuracy of the operator caused by the operator to do other work.

B. Temperature instability when the engine is operating.

C. The length of time contact the product with heat.

D. Uniformity of weight and size of raw material.

2. Measures taken for the level of protein to qualify and improve the quality of protein levels in the evaporation process are as follows:

A. Conducting Training,Briefing and formation arrangement of resting hours for the operator.

B. Revise the scheduling of water heater.

C. Check the uniformity of raw material weight at the handover of the supplier's raw materials.

D. To make improvements to the working instruction flow when filling the material into the evaporator machine.

From the improvement above the results obtained is an increase in drug protein levels of $73.43 \%$

\section{Acknowledgements}

The researcher thanked a number of parties who supported the implementation of this research and also to the lighthouse universities which helped in funding this research

\section{REFERANCE}

[1] S. Rose, "Delivering the vision," Learn. Disabil. Pract., vol. 5, no. 4, pp. 28-29, 2002, doi: 10.7748/ldp.5.4.28.s16.

[2] M. B. Witte, F. J. Thornton, U. Tantry, and A. Barbul, "L-arginine supplementation enhances diabetic wound healing: Involvement of the nitric oxide synthase and arginase pathways," Metabolism., vol. 51, no. 10, pp. 1269-1273, 2002, doi: 10.1053/meta.2002.35185.

[3] R. F. Azmi, Desmelati, and N. I. Sari, "Effect of Addition of Protein Fish Concentrates Cork ( Channa striata ) on Donuts Against Consumer Acceptance Pengaruh Penambahan Konsentrat Protein Ikan Gabus ( Channa Striata ) Pada Donat Terhadap Penerimaan Konsumen," pp. 1-16.

[4] Y. P. Pasaribu, Y. Buyang, N. L. S. Suryaningsih, A. Dirpan, and M. Djalal, "Effect of steaming and pressurized boiling process to the nutrient profile of Papuan cork fish Channa striata as potential protein-rich food to prevent stunting," Med. Clin. Pract., vol. 3, p. 100120, 2020, doi: 10.1016/j.mcpsp.2020.100120.

[5] C. Prastari, S. Yasni, and M. Nurilmala, "Characterization of snakehead fish protein that's potential as antihyperglikemik,” J. Pengolah. Has. Perikan. Indones., vol. 20, no. 2, p. 413, 2017, doi: 10.17844/jphpi.v20i2.18109.

[6] H. Kartika and D. Junaedi, "Analysis of Quality Improvement of Herbal Medicine Products from Microbial Contaminants Using the PDCA Method with the QCC Approach,” Int. J. Sci. Res., vol. 8, no. 9, pp. 291-295, 2019.

[7] A. M. Kholif, D. S. Abou El Hassan, M. A. Khorshid, E. A. Elsherpieny, and O. A. Olafadehan, "Implementation of model for improvement (PDCA-cycle) in dairy laboratories," J. Food Saf., vol. 38, no. 3, 2018, doi: 10.1111/jfs.12451.

[8] V. Arenhardt, F. de S. P. Filho, L. R. A. de Oliveira, L. S. da L. Neto, and E. E. V. Deliza, "PDCA Method for Environmental Management of Pollutants Generated in a Battery Industry in an Amazonian City,” Int. J. Adv. Eng. Res. Sci., vol. 5, no. 8, pp. 218-230, 2018, doi: 10.22161/ijaers.5.8.27.

[9] M. N. Amri, B. Susilo, and Y. Hendrawan, "Pengaruh Pengendalian Suhu Berbasis Logika Fuzzy Dan Kecepatan Pengadukan Pada Evaporator Vakum Double Jacket Terhadap Karakteristik Fisik Permen Susu The Influence of Fuzzy Logic Based Temperature Control and Mixing Speed to The Physical Characteristic o," vol. 3, no. 2, pp. 9-16, 2015.

[10] M. G. M.Purwanto, "Perbandingan Analisa Kadar Protein Terlarut dengan berbagai Metode Spektroskopi UV-Visible." Jurnal Ilmiah Sains \& Teknologi, 7 (2). pp. 64-71. ISSN 0216-1540, Surabaya, [Online]. Available: http://repository.ubaya.ac.id/24502/.

[11] M. A. Committee and A. Consultants, "Human Resource Management read as Human Resource Eight, Nine, Ten - New Concept Prof . ( Dr .) Koppula Rajanath 2020 IJLERA - All Right Reserved,” no. July, pp. 1-7, 2020. 